the experiment, he was convinced that rice was the cause of the disease. The next question was, How did the rice produce beriberi ? It was at this point that Stanton and Fraser of the Institute for Medical Research entered on their work, which not only showed exactly how rice produced beriberi but also what rice produced beriberi and what rice did not produce the disease. They showed further that the disease was not, as Braddon maintained, caused by a poison in the rice, but was a deficiency disease caused by the removal of the pericarp in the polishing of the rice; and they proved that if a fowl were suffering from beriberi as a result of being fed on a polished rice, it could be rapidly cured by giving it the polishings. They found that unpolished rice never produced beriberi in fowls, and with the introduction of unpolished rice into the jails the disease rapidly disappeared. For a time it looked as if the amount of phosphorus pentoxide $\left(\mathrm{P}_{2} \mathrm{O}_{5}\right)$ in rice could be taken as an indicator of the danger of beriberi developing, but further observations showed that this test could not be relied on.

The discovery was of great value in itself, and of vast economic importance to Malaya; so much so that had it stood alone it would have justified all the money that had been spent on the Institute for Medical Research from its foundation. But it had a still greater significance, for it suggested lines of research into other diseases, which in their turn proved to be deficiency diseases. To-day vitamins are a household word, and the accessory foodstuffs are studied in probably every country in the world. There can be few Governments which are not inquiring into and trying to improve the food of their nationals on the lines of the discovery made by Stanton and Fraser.

Space will not allow me to say much more on Stanton's work in Malaya. From 1911 until 1926 we were colleagues on the Malaria Advisory Board in the Federated Malay States, and Stanton's interest in this subject was shown not only by his valuable contributions to the discussions of the Board, but also by his researches into the morphology of the anopheline larvæ, which were of material assistance to the practical work of mosquito control and the prevention of malaria in Malaya.

May I conclude with a personal remark. No one could come into contact with Stanton without realizing that behind a quiet demeanour lay an active brain, carefully balancing the pros and cons of everything he discussed. What was perhaps not less important, he was a man who could be trusted; a scientific investigator of distinction and a great gentleman. MaLCOLM Watson.

\section{Dr. W. W. Vaughan}

News of the death on February 4 of Dr. W. W. Vaughan, as the result of an accident, will be received with deep regret by his many friends in scientific circles. A note in last week's issue of NaTURE, p. 236, described the circumstances of the unfortunate fall, while visiting the Taj Mahal at Agra, which resulted in his death. When we went to press, it was reported by cable that his condition after the amputation of his leg was favourable, and it was hoped that he would make satisfactory progress toward the recovery of his normal good health. Those, however, who saw the serious nature of the accident at the time of its occurrence, when Dr. Vaughan had to lie in the open with a compound fracture for more than an hour before an ambulance could be found to move him to the Thomason Hospital, scarcely expected that he could recover, and their fears have been sadly confirmed by the fatal result.

Dr. Vaughan was one of the few headmasters of public schools who had been presidents of the Educational Science Section of the British Association; and he was distinguished among all of them who have occupied this office in the continued part he played in the work of the Association. It was while visiting India as a member of the delegation of the Association to the jubilee meeting of the Indian Science Congress Association that he met with the accident which has led to his death.

Dr. Vaughan was born in 1865 and was the son of Prof. H. H. Vaughan, regius professor of modern history in the University of Oxford. He was educated at Rugby School, New College, Oxford, and the University of Paris; and his main subjects were modern languages. In 1890 he became an assistant master at Clifton College, where he remained until 1904, when he was headmaster of Giggleswick School. From 1910 until 1921 he was master of Wellington College, and he then returned as headmaster to his old school, Rugby, where he remained until his retirement in 1931. He was president of the Modern Language Association in 1915, of the Incorporated Association of Headmasters in 1916, of the Science Masters' Association in 1919, and of the Education Section of the British Association in 1925. He served on the Consultative Committee of the Board of Education and on the Government committee appointed in 1916 under the chairmanship of Sir J. J. Thomson, on the position of natural science in the educational system of Great Britain. At the time of his death he was a member of the Council of the British Association and of the Advisory Committee on Education in the Colonies.

When Dr. Vaughan was president of the Science Masters' Association he dealt, in his presidential address, with the importance of science as part of a liberal education. He urged that the aim of scientific instruction should not be purely utilitarian but that of education as a whole the liberation of man's soul. He referred to these objects again in his address to the Educational Science Section of the British Association. "We seem almost to have lost the will," he said, "to keep by education the pores of the soul and the mind ever open to the impressions of experience, to the stirrings of emotion, to the slow and enduring influence of the reason. We have too often pinned our faith on the production of dexterity, of mental facility, of almost thoughtless accuracy, and we have our reward in our educational looms being ill-adapted to the production of contentment and beauty and the power or the will to reason." 
It was because Dr. Vaughan cherished these high educational ideals that his influence while a school master and since his retirement is appreciated by all who have come under it. By his lamented death, the educational interests of science have suffered a severe loss and his many scientific friends have to mourn the passing into silence of a helpful colleague.

We regret to announce the following deaths:

Prof. H. H. Donaldson, for thirty-two years professor of neurology in the Wistar Institute of Anatomy and Biology, Philadelphia, known for his work on growth, particularly of the nervous system, on January 23, aged eighty years.
Mr. Alan E. Munby, architect of Clifton College Science School and other important science lab. oratories, on January 19, aged sixty-eight years.

Dr. Andrei Vassilievitch Martynov, professor in the Institute of Palæontology at Moscow, well known for his work on Trichoptera and fossil insects, on January 29, aged fifty-nine years.

Dr. F. G. Pease, of Mount Wilson Observatory, where he was responsible for the design of many large instruments, on February 7, aged fifty-seven years.

Prof. Herman Schlundt, chairman of the Department of Chemistry of the University of Missouri, known for his work on radioactivity, on December 30 , aged sixty-eight years.

\section{News and Views}

\section{The London School of Economics}

IN a leading article on "Realistic Social Studies" in NATURE of January 22, incidental reference was made to the London School of Economics and it was stated "that responsible bodies which administer funds for research . . . have refused to renew temporary grants such as the Rockefeller subsidy to the London School". We are informed that the facts with regard to the Rockefeller Foundation are as follows : "During the past three years, four temporary grants from the Foundation to the School have been in force. Two of these for the purpose of site extension and library development still remain available; a third, providing funds for research, terminated in 1935 and was then renewed on a somewhat different basis for a five-year period; the fourth grant, providing facilities for post-graduate teaching and research, does not expire until the end of the current academic year. No formal application has yet been made by the School for the renewal of this grant: hence, no action has yet been taken. If the editorial of January 22 seems to imply that there has been any criticism offered or expressed by 'responsible bodies which administer funds for research' such an implication does not exist. In point of fact, no criticism as to the teaching and research in economics under way at the London School has ever been made on the part of any Foundations which have assisted it in the past and assist it now." The context of our comment made it clear that it referred to the grant which terminated in 1935, and that it had no relevance to any allocations for the purchase of books, for site extension or for post-graduate instruction. We were in receipt of full information concerning the "somewhat different basis" on which the grant was renewed. If, as we understand, the previous annual grant which terminated in 1935 was replaced by a reduced and tapering allocation, there seems little ground for objection to the statement published in our editorial. The main purpose of the article was to urge that the new Institute of Economic and Social Research should "tackle the fundamental problems arising from the way in which expanding technical resources react upon, and are used by, existing social institutions" ; and the purpose will have been served if the article leads to the extension of social research in these directions. With Prof. Carr-Saunders as the new director of the School it may confidently be expected that increased encouragement will be given to such studies.

\section{American Institute Awards}

Dr. W. Crocker has been awarded the Gold Medal of the American Institute of the City of New York for "his contribution to knowledge of life processes in plants and for his unique leadership in the organization of plant research". Dr. Crocker was professor and director of research in plant physiology at the University of Chicago for many years. He organized and has directed the Boyce Thompson Institute for Plant Research from the time it was founded in 1921 to the present day. At the University of Chicago and the Boyce Thompson Institute for Plant Research he has acquired a reputation as an organizer and director of research. His method has been to bring together specialists in different fields of knowledge and to give these specialists an opportunity to work co-operatively on biological problems that have not yielded to attacks by individuals working single-handed. Dr. Crocker has also done noteworthy research. He was the first to show that ethylene gas in air in amounts far too small to be detected by any known chemical means causes profound reactions in plants. $\mathrm{He}$ 